Trakya Üniversitesi

Eğitim Fakültesi Dergisi

XV. Uluslararası Katılımlı Sınıf Öğretmenliği

Eğitimi Sempozyumu (11-14 Mayıs 2016)

USOS 2016 Özel Sayısı, 28-46

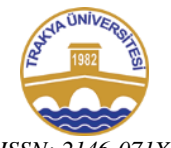

ISSN: 2146-071X
Trakya University

Journal of Education Faculty

XV. International Primary Teacher Education

Symposium (11-14 May 2016)

IPTES 2016 Special Issue, 28-46

Doi: $10.24315 /$ trkefd.364015

Geliș Tarihi: 13.11.2016

Yayına Kabul Tarihi: 27.07.2017

\title{
Sınıf Öğretmenlerinin Fen Öğretiminde Karşılaştıkları Sorunlar ${ }^{1}$
}

\section{The Problems of Primary School Teacher Faced in the Science Teaching Process}

\author{
Mustafa Zafer BALBA $\breve{G}^{2}$, Gamze KARAER ${ }^{3}$
}

\begin{abstract}
Öz: İlkokul çağında fen bilimlerinin öğretimi sınıf öğretmenleri tarafindan gerçekleştirilmektedir. Çocuklar bu derste, doğadaki varlıkları ve olayları bilimsel yönden ele alıp; gözlem yapma, inceleme ve anlama olanağ 1 elde ederler. İlkokulda fen bilimleri öğretiminde karşılaşılan sorunları ve bunlara yönelik çözümlerin üretilmesini en iyi ortaya koyacak kişiler sınıf öğretmenleridir. Sınıf öğretmenlerinin hitap ettikleri yaş grubuna göre karşılaştıkları sorunlar da farklı olabilmektedir. Buna göre bu araştırmanın amacı, sınıf öğretmenlerinin fen öğretimi sürecinde yaşadıkları sorunları ve bu sorunların çözümüne yönelik önerilerini belirlemektir. Araştırmanın çalışma grubunu, 2015-2016 eğitim-öğretim y1lında Eskişehir il merkezinde bulunan okullarda görev yapan 20 sinıf öğretmeni oluşturmaktadır. Veri toplama aracı olarak araştırmacılar tarafindan geliştirilen ve açık uçlu sorulardan oluşan yarı yapılandırılmış görüşme formu kullanılmıştır. Elde edilen nitel veriler araştırmacılar tarafından analiz edilerek değerlendirilmiştir.
\end{abstract}

Anahtar sözcükler: Fen, fen bilimleri öğretimi, sınıf ögrretmeni, sorun

\begin{abstract}
Science teaching is carried out by primary school teacher in the primary school. Children find an opportunity to observation, investigation and understanding creatures and events in the nature by dealing with scientifically. Primary school teachers who take place in the teaching process are most essential persons in order to reveal problems faced in the primary school science teaching and find a solution towards these problems. Due to students' age, primary school teachers can be exposed different science teaching problems. Depending on all reasons, this study was to aim that determining the problems of primary school teachers in the science teaching process and the views of primary school teachers towards solving these problems. The sample of study consisted of 20 primary school
\end{abstract}

\footnotetext{
1 Bu çalışma 11-14 Mayıs 2016 tarihinde Muğla Sttkı Koçman Üniversitesi tarafindan düzenlenen XV. Uluslararası Sınıf Öğretmenliği Eğitimi Sempozyumu'nda sözlü bildiri olarak sunulmuştur.

2 Doç.Dr., Eskişehir Osmangazi Üniversitesi, zbalbag@ogu.edu.tr

3 Doktora Öğrencisi, Eskişehir Osmangazi Üniversitesi, gmzkaraer26@gmail.com
} 
teachers who work at primary schools in Eskisehir in the 2015-2016 school years. Data was conducted with form of semi-structured interview which consisted of open ended questions and was developed by researchers. The qualitative data obtained end of the research was evaluated analyzing by the researchers.

Keywords: Science, science teaching, primary school teachers, problem

\section{GíRiş}

Bilimsel bilgi üretiminin gittikçe arttığı günümüzde, fen bilimlerinin etkilerinin yaşantımızın her alanında belirgin bir şekilde görüldüğü bilgi çağında, toplumların geleceği açısından çok önemli olan fen eğitiminin anahtar bir rol oynadığ görülmektedir. Bu bağlamda, başta gelişmiş ülkeler olmak üzere bütün toplumlar sürekli bir şekilde fen bilimleri eğitimini yaygınlaştırma ve kalitesini daha da arttırma uğraşı içerisine girmişlerdir. Bu nedenle, hemen hemen her eğitim kademesinde ve okullarda fen bilgisi eğitimi ve öğretimi önemli bir yer kapsamaktadır. Fen bilgisi veya fen grubu dersleri dünyanın birçok ülkesinde olduğu gibi Türkiye'de de temel derslerin içerisinde yer almaktadır (Türkmen, 2002). Öğrencilerin Fen'e ilişkin becerileri elde edebilmeleri ve günlük hayatta kullanabilmeleri için okul içi ve okul dişı eğitim öğretim ortamlarının onların zihinsel ve bilişsel gelişimlerini destekleyici şekilde düzenlenmesi büyük önem taşımaktadır. Bu doğrultuda hazırlanan 2005, 2013 ve 2017 fen bilimleri öğretim programları öğrencilerin öğrenme sürecinde aktif olabilecekleri, karşılaştıkları problemlere çözüm üretebilen ve sorumluluk sahibi bireyler olabilmeleri için yapılandırılmışlardır (Milli Eğitim Bakanlığı, [MEB], 2005; MEB, 2013; MEB, 2017). İlkokul çağında fen bilimlerinin öğretimi sınıf öğretmenleri tarafından gerçekleştirilmektedir. 2013 yılında revize edilen Fen Bilimleri Öğretim Programı ile Fen Bilimleri dersi ilkokul üçüncü sınıftan itibaren okutulmaya başlanmıştır. Böylece çocuklara erken yaşlarda, doğadaki varlıkları ve olayları bilimsel yönden ele alıp; gözlem yapma, inceleme ve anlama olanağı sunulmuştur (MEB, 2013). İlköğretim düzeyinde verilen fen eğitimi ile öğrenciler, fen dersine ilişkin bilgilerin ortaya çıkmasını destekleyen temel kavram, ilke, yasa ve kuramları anlama ve uygulama, bilimsel çalışmaların yapısını bilme, bilimsel gelişmenin tarihini, fen ve teknoloji arasındaki ilişkiyi ve bu ilişkilerin içinde gerçekleştiği sosyal, kültürel ve tarihsel bağlamı bilme firsatını elde ederler (Trowbridge, Bybee,\&Powell, 2004).

Fen bilimleri dersinin öğrenciler ve gelecek nesiller için önemi dikkate alındığında fen öğretimi daha da önem kazanmaktadır. Öğrencilerin ilk kez fen bilimleri dersiyle tanışmalarının ilkokulda olduğu düşünüldüğünde fen bilimleri dersinin öğretimine ilişkin sınıf öğretmenlerine büyük sorumluluk düşmektedir (Genç, Deniş\&Demirkaya, 2010). Bu doğrultuda sınıf öğretmenlerinin üzerlerine düşen sorumlulukları yerine getirebilmeleri için fen bilimleri öğretim sürecinde karşılaşılan sorunların minimum düzeye indirgenmesi gerekmektedir. Literatür incelemesi sonucunda, ilgili çalışmalar fen bilimleri öğretiminde pek çok sorunla karşılaşıldığını göstermektedir. Ancak bu çalışmaların genelinde, fen bilgisi öğretmenlerinin fen öğretiminde karşılaştıkları sorunlara değinilmektedir. $\mathrm{Bu}$ sorunların; ölçme ve değerlendirme, 5E modelinin uygulanma aşaması, fen 
laboratuvar uygulamaları, fen ve teknoloji öğretim programı, araç-gereç eksikliği, istenmeyen öğrenci davranışları gibi konular olduğu belirtilmektedir (Balbağ\&Karaer, 2016, Ayvacı\&Durmuş, 2013; Ayvacı\&Bakırc1, 2012; Kaya\&Böyük, 2011; Doğan, 2010; Küçüköner, 2011). Balbağ, vd. (2016)’ ya göre, 2010 ve 2015 yılları arasında Türkiye'de fen öğretiminde karşılaşılan sorunlar, öğretmenden kaynaklı sorunlar; fiziki ve çevresel koşullardan kaynaklı sorunlar; öğrenci kaynaklı sorunlar ve program kaynaklı sorunlar olarak dört başlıkta toplanarak bütüncül bir şekilde ortaya konmuştur. Balbağ\&Karaer, (2016) tarafindan yapılan çalışmaya göre, fen bilgisi öğretmenlerinin görüşleri doğrultusunda fen öğretimi sürecinde en çok karşılaşılan sorunlar, öğretim programından, eğitim-öğretim sürecinden, öğrenciden, fiziki koşullardan ve öğretmenden kaynaklı sorunlar olarak belirtilmiştir. İlgili çalışmaların incelenmesi sonucunda sınıf öğretmenlerinin fen öğretimi sürecinde karşılaştıkları sorunlara yönelik öğretmen görüşlerinin alındığı ve fen öğretiminde karşılaşılan sorunları bütüncül olarak ele alan çalışmaların azlığı dikkat çekmektedir. İlgili çalışmalarda sınıf öğretmenlerinin çoğunlukla fen bilimleri öğretiminde özyeterlik ve bilimsel süreç becerilerinin analizinde yetersizlik ve fen alanına hâkim olamama gibi konularda sorunlar yaşadıkları belirtilmiştir (Akbaş\&Çelikkaleli, 2006; Gömleksiz, Kan,\&Biçer, 2010). Alanyazında yapılan çalışmalar fen bilimleri laboratuvar uygulamalarında sorunların yaşandığı göstermektedirler(Akbaş\&Çelikkaleli, 2006; Gömleksiz, Kan\&Biçer, 2010; Türkmen\&Kandemir, 2011; Türkmen, 2002). Küçük, Altun\&Paliç (2013), sınıf öğretmenleri üzerine yaptıkları çalışmada öğretmenler arası işbirliğinin önemini vurgulanmışlardır. Bu çalışmaya göre, sınıf öğretmenlerinin fen ve teknoloji öğretmenleri ile daha aktif bir iletişim kurmaları ve işbirliği içinde bulunmaları halinde onların fen öğretiminde öz-yeterlik inançlarının artabileceği belirtilmektedir. Öğretmenler fen öğretim sürecinin en önemli tanıklarıdırlar ve onların görüşleri fen öğretimi sürecinde karşılaşılan sorunların ve bu sorunlara çözüm üretilmesinin en önemli belirleyicileridirler (Balbağ\&Karaer 2016). Buradan hareketle fen öğretiminde önemli bir yere sahip olan sınıf öğretmenlerinin görüşleri doğrultusunda fen öğretim sürecinde karşılaşılan sorunların bütüncül olarak ele alınması bu araştırmanın önemini ortaya koymaktadır.

$\mathrm{Bu}$ araştırmanın amacı, sınıf öğretmenlerinin fen öğretimi sürecinde yaşadıkları sorunları ve bu sorunlara yönelik çözüm önerilerini ortaya çıkarmaktır. $\mathrm{Bu}$ amaç doğrultusunda aşağıdaki alt amaçlar belirlenmiştir.

Sınıf öğretmenlerinin fen öğretimi sürecinde yaşadıkları sorunlar nelerdir?

Sınıf öğretmenlerinin fen öğretimi sürecinde yaşadıkları sorunlar yönelik çözüm önerileri nelerdir?

\section{YÖNTEM}

$\mathrm{Bu}$ araştırmada nitel araştırma yaklaşımı benimsenmiştir. Bu kapsamda nitel araştırma tekniklerinden yarı yapılandırılmış görüşme tekniğiyle veriler toplanmıştır. 


\subsection{Katılımcılar}

Araştırmanın çalışma grubunu, 2015-2016 eğitim-öğretim yılı bahar döneminde Eskişehir ili merkez okullarında görev yapan, üçüncü ve dördüncü sınıflarda eğitim veren 20 sınıf öğretmeni oluşturmaktadır. Tablo 1'de katılımcıların özellikleri verilmiştir.

Tablo 1. Katılımcıların Özellikleri

\begin{tabular}{|c|c|c|c|c|}
\hline Öğretmen & Cinsiyet & Kıdem & $\begin{array}{l}\text { Mezun Olunan } \\
\text { Fakülte/ Bölüm }\end{array}$ & $\begin{array}{l}\text { Lisans Eğitimi } \\
\text { Haricinde } \\
\text { Herhangi Bir } \\
\text { Eğitim Alıp } \\
\text { Almama Durumu }\end{array}$ \\
\hline Ö1 & Kadın & $\begin{array}{l}21 \text { y1l ve } \\
\text { üzeri }\end{array}$ & $\begin{array}{l}\text { Eğitim Fakültesi- } \\
\text { Sınıf Öğretmenliği }\end{array}$ & $\begin{array}{l}\text { Hizmet içi eğitim } \\
\text { seminerleri }\end{array}$ \\
\hline$\ddot{0} 2$ & Kadın & $\begin{array}{l}21 \text { y1l ve } \\
\text { üzeri }\end{array}$ & $\begin{array}{l}\text { Eğitim Fakültesi- } \\
\text { Fransızca } \\
\text { Öğretmenliği }\end{array}$ & - \\
\hline Ö3 & Kadın & $\begin{array}{l}21 \text { y1l ve } \\
\text { üzeri }\end{array}$ & $\begin{array}{l}\text { Eğitim Fakültesi- } \\
\text { Sinıf Öğretmenliği }\end{array}$ & $\begin{array}{l}\text { Hizmet içi eğitim } \\
\text { seminerleri }\end{array}$ \\
\hline Ö4 & Kadın & $11-20$ y1l & $\begin{array}{l}\text { Eğitim Fakültesi- } \\
\text { Sinıf Öğretmenliği }\end{array}$ & - \\
\hline 0̈5 & Kadın & $\begin{array}{l}21 \text { y1l ve } \\
\text { üzeri }\end{array}$ & $\begin{array}{l}\text { Eğitim Fakültesi- } \\
\text { Sinıf Öğretmenliği }\end{array}$ & - \\
\hline Ö6 & Erkek & $\begin{array}{l}21 \text { y1l ve } \\
\text { üzeri }\end{array}$ & $\begin{array}{l}\text { Eğitim Fakültesi- } \\
\text { Sinıf Öğretmenliği }\end{array}$ & - \\
\hline Ö7 & Erkek & $\begin{array}{l}21 \text { y1l ve } \\
\text { üzeri }\end{array}$ & $\begin{array}{l}\text { Eğitim Fakültesi- } \\
\text { Sinıf Öğretmenliği }\end{array}$ & $\begin{array}{l}\text { Hizmet içi eğitim } \\
\text { seminerleri }\end{array}$ \\
\hline Ö8 & Erkek & $\begin{array}{l}21 \text { y1l ve } \\
\text { üzeri }\end{array}$ & $\begin{array}{l}\text { Eğitim Fakültesi- } \\
\text { Sinıf Öğretmenliği }\end{array}$ & - \\
\hline Ö9 & Kadın & $\begin{array}{l}21 \text { y1l ve } \\
\text { üzeri }\end{array}$ & $\begin{array}{l}\text { Fen Fakültesi- } \\
\text { İstatistik Bölümü }\end{array}$ & $\begin{array}{l}\text { Hizmet içi eğitim } \\
\text { seminerleri } \\
\text { Fen deneyleri kursu }\end{array}$ \\
\hline Ö10 & Erkek & $\begin{array}{l}21 y 1 l \text { ve } \\
\text { üzeri }\end{array}$ & $\begin{array}{l}\text { Eğitim Fakültesi- } \\
\text { Sinıf Öğretmenliği }\end{array}$ & $\begin{array}{l}\text { Hizmet içi eğitim } \\
\text { seminerleri } \\
\text { Fen deneyleri kursu }\end{array}$ \\
\hline Ö11 & Erkek & $\begin{array}{l}21 \text { y1l ve } \\
\text { üzeri }\end{array}$ & $\begin{array}{l}\text { Eğitim Fakültesi- } \\
\text { Sinıf Öğretmenliği }\end{array}$ & Fen deneyleri kursu \\
\hline Ö12 & Kadın & $\begin{array}{l}21 \text { y1l ve } \\
\text { üzeri }\end{array}$ & $\begin{array}{l}\text { İktisadi İdari } \\
\text { Bilimler } \\
\text { Fakültesi }\end{array}$ & $\begin{array}{l}\text { Hizmet içi eğitim } \\
\text { seminerleri }\end{array}$ \\
\hline Ö13 & Kadın & $11-20$ y1l & $\begin{array}{l}\text { Fen Edebiyat } \\
\text { Fakültesi- Biyoloji }\end{array}$ & - \\
\hline Ö14 & Kadın & $\begin{array}{l}21 \text { y1l ve } \\
\text { üzeri }\end{array}$ & $\begin{array}{l}\text { Eğitim Fakültesi- } \\
\text { Sinıf Öğretmenliği }\end{array}$ & - \\
\hline
\end{tabular}




\begin{tabular}{|c|c|c|c|c|}
\hline Ö15 & Kadın & $\begin{array}{l}21 \text { yll ve } \\
\text { üzeri }\end{array}$ & $\begin{array}{l}\text { Yabancı Diller- } \\
\text { Fransızca } \\
\text { Öğretmenliği }\end{array}$ & $\begin{array}{l}\text { Hizmet içi eğitim } \\
\text { seminerleri } \\
\text { Fen deneyleri kursu }\end{array}$ \\
\hline Ö16 & Erkek & $\begin{array}{l}21 \text { y1l ve } \\
\text { üzeri }\end{array}$ & $\begin{array}{l}\text { Eğitim Fakültesi- } \\
\text { Sınıf Öğretmenliği }\end{array}$ & - \\
\hline Ö17 & Kadın & $\begin{array}{l}21 \text { y1l ve } \\
\text { üzeri }\end{array}$ & $\begin{array}{l}\text { Eğitim Fakültesi- } \\
\text { Sınıf Öğretmenliği }\end{array}$ & \\
\hline Ö18 & Kadın & $11-20 \mathrm{y} 1 \mathrm{l}$ & $\begin{array}{l}\text { Eğitim Fakültesi- } \\
\text { Sinıf Öğretmenliği }\end{array}$ & $\begin{array}{l}\text { Hizmet içi eğitim } \\
\text { seminerleri }\end{array}$ \\
\hline Ö19 & Erkek & $\begin{array}{l}21 \text { y1l ve } \\
\text { üzeri }\end{array}$ & $\begin{array}{l}\text { Eğitim Fakültesi- } \\
\text { Sınıf Öğretmenliği }\end{array}$ & $\begin{array}{l}\text { Hizmet içi eğitim } \\
\text { seminerleri }\end{array}$ \\
\hline Ö20 & Kadın & $\begin{array}{l}21 \text { y1l ve } \\
\text { üzeri }\end{array}$ & $\begin{array}{l}\text { Fen Edebiyat } \\
\text { Fakültesi- Biyoloji } \\
\text { Bölümü }\end{array}$ & $\begin{array}{l}\text { Hizmet içi eğitim } \\
\text { seminerleri }\end{array}$ \\
\hline
\end{tabular}

Tablo'1 de görüldüğü gibi, katılımcıların 13'ü kadın, yedisi erkektir. Katılımcıların kıdem yılına bakıldığında 17 tanesi 21 yıl ve üzeri, üç tanesi ise 1120 yıl arası kıdeme sahiptir. Katılımcıların mezun oldukları fakülte ve bölümlere bakıldığında 14 öğretmen eğitim fakültesi sınıf öğretmenliği mezunudur. Diğer altı öğretmen ise eğitim fakültesi Fransızca bölümü (Ö2), fen fakültesi İstatistik bölümü (Ö9), iktisadi idari bilimler fakültesi (Ö12), fen edebiyat fakültesi Biyoloji bölümü (Ö13; Ö20) ve yabancı diller Fransızca öğretmenliği bölümü (Ö15) mezunu oldukları görülmektedir. Katılımcıların 10'u hizmet içi eğitim seminerlerine katılırken, dört tanesi fen deneyleri kursuna katılmıştır. On öğretmen ise lisans eğitimi haricinde herhangi bir eğitim almadığını belirtmiştir.

\subsection{Verilerin Toplanması}

Araştırma verilerinin toplanmasında yarı yapılandırılmış görüşme formu kullanılmıştır. Yarı yapılandırılmış görüşmeler, analizlerin kolaylığı, görüşülene kendini ifade etme imkânı, gerektiğinde derinlemesine bilgi sağlama gibi avantajlara sahiptir (Büyüköztürk, Kılıç, Akgün, Karadeniz,\&Demirel, 2009). Araştırmada kullanılan görüşme formu iki bölümden oluşmuştur. Birinci bölüm sınıf öğretmenlerinin cinsiyeti, kıdem yılı, mezun olunan bölüm ve fen öğretimi ile ilgili lisans eğitimi haricinde herhangi bir eğitim alıp almama durumları ile ilgili sorulardan oluşmaktadır. İkinci bölüm ise sınıf öğretmenlerinin fen öğretim sürecinde karşılaştığı sorunları ve bu sorunlara yönelik çözüm önerilerini ortaya çıkarmaya yönelik sorular yer almaktadır. Araştırma verilerini toplamak için her bir öğretmen ile araştırma sorularının yöneltildiği 30-45'er dakikalık görüşmeler yapılmıştır. Görüşmeler esnasında veriler görüşme formlarına not alınarak ve ses kayıt cihazı ile kayıt altına alınmıştır.

\subsection{Verilerin Analizi}

Araştırma kapsamında yarı yapılandırılmış görüşme tekniğiyle toplanan nitel veriler tümevarımsal bir şekilde analiz edilmiştir. Araştırmanın güvenirliğini sağlamak amacıyla araştırmanın verileri iki araştırmacı tarafından ayrı ayrı analiz edilmiştir. Yapılan bu analizler sonucunda kodlar ve temalar karşılaştırılmış, görüş 
ayrılığına düşülen noktalar belirlenmiş, bunun üzerine gerekli tartışmalar yapılarak temalara son şekli verilmiştir.

\section{BULGULAR}

Araştırmadan elde edilen bulgular, "Sınıf Öğretmenlerinin Fen Öğretimi Sürecinde Karşılaştığı Sorunlara Yönelik Görüşleri” ve "Sınıf Öğretmenlerinin Fen Öğretimi Sürecinde Karşılaştığı Sorunların Çözümüne Yönelik Görüşleri” temaları altında sunulmuştur.

\subsection{Sınıf Öğretmenlerinin Fen Öğretimi Sürecinde Karşılaştığı Sorunlara Yönelik Bulgular}

Sınıf öğretmenlerinin fen öğretiminde karşılaştıkları sorunlara yönelik görüşleri incelendiğinde, bu sorunların öğretim programından; eğitim-öğretim sürecinden; fiziki yetersizliklerden, öğrenci ve öğretmenden kaynaklı sorunlar olduğu görülmektedir. Elde edilen bulgular Şekil 1'de sunulmuştur.

Şekil 1. Sınıf öğretmenlerinin fen öğretim sürecinde karşılaştıkları sorunların yönelik bulgular

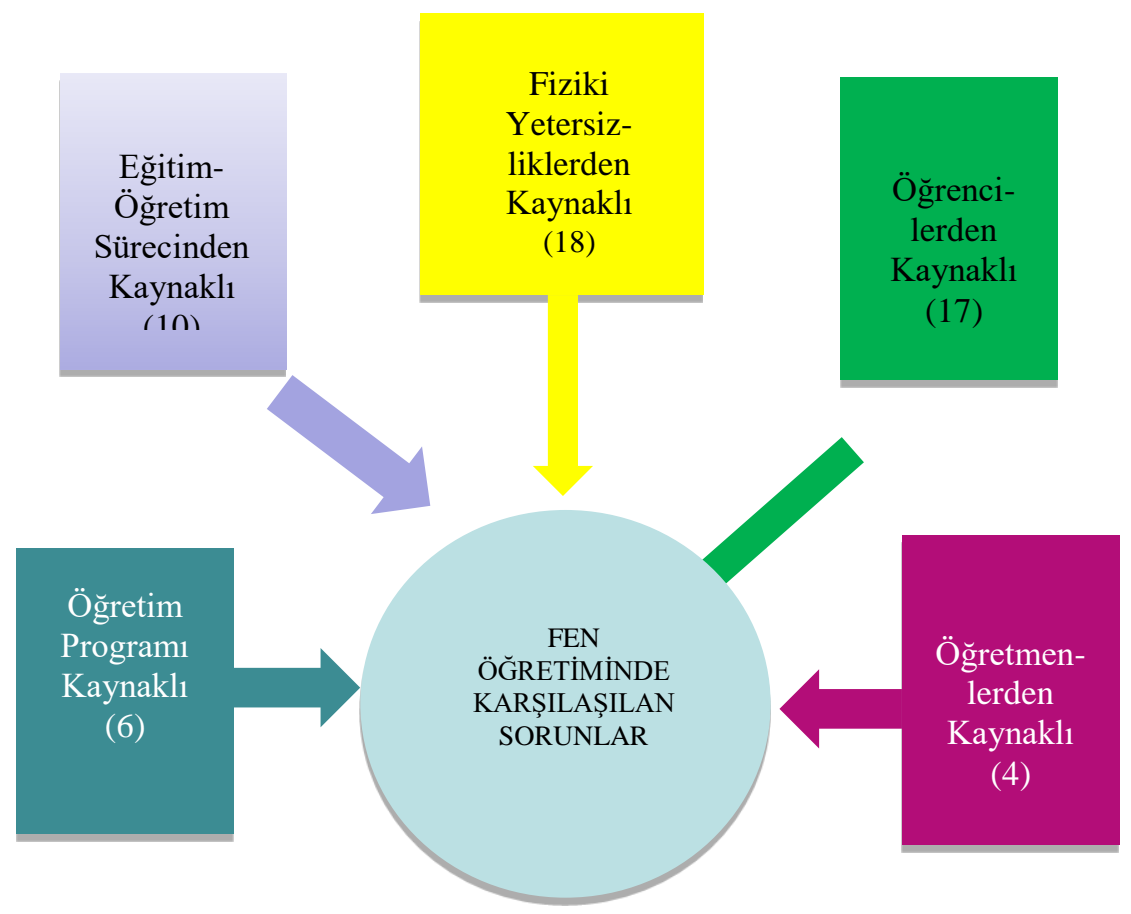




\subsection{1. Öğretim Programı Kaynaklı Sorunlara Yönelik Bulgular}

Sınıf öğretmenlerinin görüşleri doğrultusunda elde edilen öğretim programı kaynaklı sorunlar Tablo 2'de verilmiştir.

Tablo 2. Öğretim programı kaynaklı sorunlar

\begin{tabular}{lcl}
\hline Kodlar & f & \multicolumn{1}{c}{ İfadeler } \\
\hline $\begin{array}{l}\text { Sürekli değişime } \\
\text { uğramakta }\end{array}$ & 1 & -Fen bilgisi dersinin sık sık gereksiz yere adı değişiyor (Ö1). \\
\hline $\begin{array}{l}\text { Öğrenci seviyesi } \\
\text { üzerinde }\end{array}$ & $3 \begin{array}{l}\text {-Bazı konular seviye üzerinde (Ö4). } \\
\text {-Programın ünite sayısı çok fazla, çocuklar kolay anlamıyor. } \\
\text { Çocuk seviyesine göre hazırlanmamış (Ö10). } \\
\text {-Dördüncü sınıflar için çok ayrıntıll program. Gereksiz } \\
\text { ayrıntılarla zaman geçiyor. Özellikle vücudumuzu tanıyalım } \\
\text { ünitesinde sanki tıp öğrencisi yetişiyor, Fen bilgisi dersi } \\
\text { üçüncü sınıflar için ağır bir ders.(Ö1). }\end{array}$ \\
\hline Yüzeysel konular & 1 & - Üçüncü sınıflarda konular çok yüzeysel (Ö16). \\
\hline $\begin{array}{l}\text { Program açıklayıcı } \\
\text { değil }\end{array}$ & 1 & $\begin{array}{l}\text {-Program konu olarak iyi verilmiş fakat etkinlik olarak } \\
\text { ayrıntı yok (Ö9). }\end{array}$ \\
\hline
\end{tabular}

Tablo 2’de görüldüğü gibi öğretim programı kaynaklı sorunlar sürekli değişime uğramakta, öğrenci seviyesi üzerinde, yüzeysel konular ve program açıklayıcı değil boyutlarıyla ortaya çıkmıştır. Fen bilimleri öğretiminde sınıf öğretmenlerinin geneli öğretim programından kaynaklı sorunlar yaşadıklarını belirtirken (Ö1;Ö4;Ö10;Ö16;Ö19), sekiz öğretmen program kaynakl1 sorun yaşamadıklarını belirtmiştir (Ö2; Ö3; Ö11; Ö13; Ö15; Ö17; Ö18; Ö20). Fen bilimleri öğretiminde sınıf öğretmenlerinin geneli öğretim programından kaynaklı sorunlar yaşadıklarını belirtirken, sekiz öğretmen program kaynaklı sorun yaşamadıklarını belirtmiştir (Ö2; Ö3; Ö11; Ö13; Ö15; Ö17; Ö18; Ö20).

\subsubsection{Eğitim-öğretim sürecinde karşılaşılan sorunlara yönelik bulgular}

Sınıf öğretmenlerinin görüşleri doğrultusunda eğitim-öğretim sürecinde karşılaşılan sorunlara ait bulgular Tablo 3'de verilmiştir. Tablo 3 incelendiğinde eğitim-öğretim sürecinden kaynaklı sorunların süre sıkıntısı, kitapların yetersizliği ve günlük hayat ile ilişkilendirmeden oluştuğu görülmektedir.

Tablo 3. Eğitim-öğretim sürecinde karşılaşılan sorunlar

\begin{tabular}{lll}
\hline Kodlar & $\mathrm{f}$ & İfadeler \\
& & $\begin{array}{l}\text {-Ders saatleri yetersiz. Program ana hatlarıyla öğretiliyor fakat } \\
\text { planlarda sınırlandırıyor (Ö12). }\end{array}$ \\
& -Ders saati konusunda programda olan etkinliklerin \\
& uygulanması sıkıntı yaratıyor (Ö8). \\
& -Öğretim yapılacak konular, bakımından öğretimi kısıtlıyor. \\
& Çünkü ders saatleri yetersiz (Ö19). \\
& -Yaparak, yaşayarak ve göstererek yapmak için yeterli imkân \\
& yok (Ö2). \\
\hline & - Kitaplarının yetersiz olduğunu düşünüyorum. Bu yüzden farklı \\
& kaynaklar kullanıyoruz (Ö9). \\
& -Ders kitapları güzel fakat çalışma kitapları yok (Ö14).
\end{tabular}




\begin{tabular}{ll}
\hline $\begin{array}{l}\text { Kitaplar } \\
\text { yetersiz }\end{array}$ & $\begin{array}{l}\text {-Öğretmen kılavuz kitapları hazır değil (Ö7). } \\
\text {-Çalışma kitapları ve ders kitapları ayrı değil (Ö16). } \\
\text {-Kaynak eksikliği var (Ö13) }\end{array}$ \\
\hline $\begin{array}{l}\text { Günlük hayat } \\
\text { ile } \\
\text { ilişkilendirme }\end{array}$ & $\begin{array}{l}\text {-Öğrencilere teorik bilgi veriliyor fakat günlük hayatta ne işe } \\
\text { yarayacağı verilmiyor (Ö16). }\end{array}$ \\
\hline
\end{tabular}

Elde edilen bulgular doğrultusunda sınıf öğretmenlerinin geneli eğitimöğretim sürecinde sorunlarla karşılaşırken, dokuz öğretmen sorun yaşamadığını belirtmiştir (Ö3; Ö4; Ö5; Ö6; Ö11; Ö14; Ö15; Ö17; Ö18). Eğitim öğretim sürecinde sorun yaşadığını ifade eden öğretmenlerin görüşleri Tablo 3 'te yer almaktadır. Eğitim öğretim sürecinde sorun yaşamadığını ifade eden Ö6 görüşlerini "Haftalık üç saat şu anki konu dağllımına göre yeterli sayllır" ş̧eklinde ifade ederken Ö7 ise "Dersin ǚ̧üncü sinıflarda başlaması olumludur. Gerekli materyallerin okullara verilmesi gereklidir" şeklinde ifade etmiştir. (Ö7).

\subsubsection{Fiziki yetersizliklerden dolayı karşılaşılan sorunlara yönelik bulgular}

Sınıf öğretmenlerinin görüşleri doğrultusunda fiziki yetersizliklerden dolayı karşılaşılan sorunlara ait bulgular Tablo 4'te verilmiştir. Tablo 4 incelendiğinde fiziki yetersizliklerden kaynaklı sorunların laboratuvar-araç gereç ve kalabalık sınıflar olmak üzere iki farklı kodlamadan oluştuğu görülmektedir.

Tablo 4. Fiziki yetersizliklerden kaynaklı sorunlar

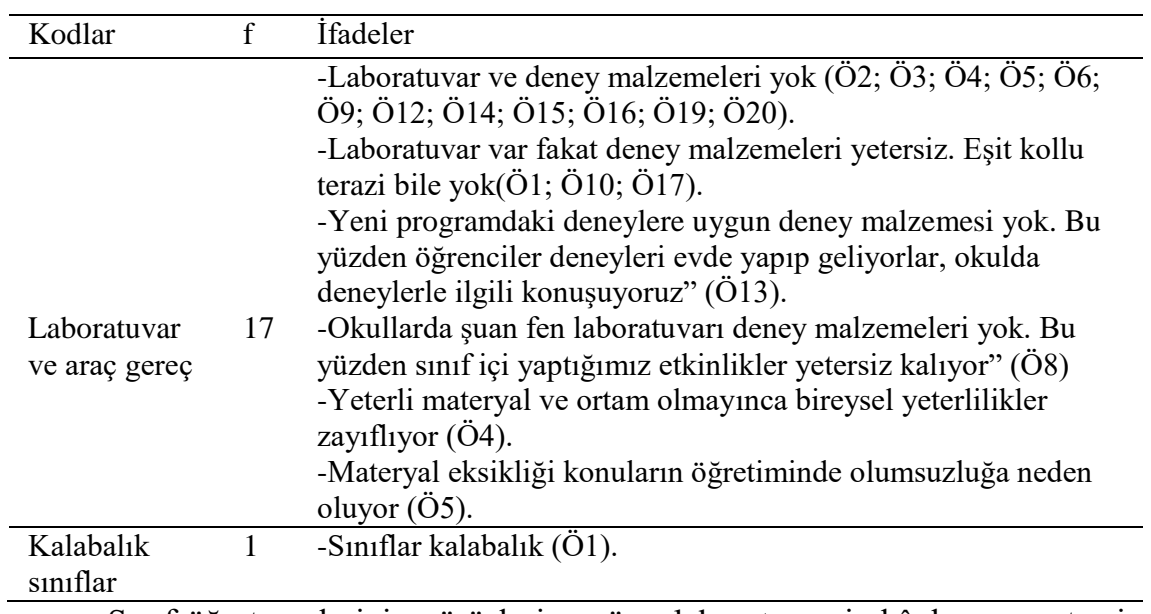

Sınıf öğretmenlerinin görüşlerine göre, laboratuvar imkânlarının yetersiz oluşu ve deney malzemelerinin eksikliği çoğunlukla sorun olarak belirtilmektedir. $\mathrm{Bu}$ bulgulara ek olarak sinıf mevcudu da bir sorun olarak belirtilirken, iki öğretmen okulun imkân yetersizliklerini sorun olarak belirtmemiştir (Ö11; Ö18).

\subsection{4. Öğrencilerden kaynaklı sorunlara yönelik bulgular}


Öğrencilerden kaynaklı sorunlara ait bulgular Tablo 5'de verilmiştir. Tablo 5'e bakıldığında öğrencilerden kaynaklı sorunların bireysel farklılıklar ve hazırbulunuşluk olmak üzere iki farklı kodlamadan oluştuğu görülmektedir.

Tablo 5. Öğrencilerden kaynaklı sorunlar

\begin{tabular}{|c|c|c|}
\hline Kodlar & $\mathrm{f}$ & İfadeler \\
\hline $\begin{array}{l}\text { Bireysel } \\
\text { farklılıklar }\end{array}$ & 15 & $\begin{array}{l}\text {-Fen konularına çok meraklılar, bu yüzden ilgi yüksek (Ö2; Ö3). } \\
\text {-Genelde dersi sevdikleri için hazır geliyorlar (Ö6; Ö7; Ö8; Ö9; } \\
\text { Ö10; Ö11; Ö13; Ö15; Ö16; Ö18). } \\
\text {-Çevreye göre ve öğrenciye göre anlamalarında farkl1lıklar } \\
\text { oluyor, değişiyor (Ö5). } \\
\text {-Öğrencilerin aileleri bazen ilgisiz olabiliyor. Bu bölgede çoğu } \\
\text { ailenin eğitim durumunun düşük olması öğrencileri etkiliyor } \\
\text { (Ö20). } \\
\text {-Veli desteği yok (Ö13). }\end{array}$ \\
\hline $\begin{array}{l}\text { Hazır- } \\
\text { bulunuşluk }\end{array}$ & 2 & $\begin{array}{l}\text {-Zaman zaman hazırbulunuşluk düzeyleri olmuyor (Ö4). } \\
\text {-Çevre şartlarına göre hazırbulunuşlukları öğrenciden öğrenciye } \\
\text { değişiyor (Ö5). }\end{array}$ \\
\hline
\end{tabular}

Tablo 5 incelendiğinde öğrencilerden kaynaklı sorunlar bireysel farklılıklar ve hazırbulunuşluk düzeyleri olarak ortaya çıkmıştır. Ayrıca öğretmenlerden bazıları da öğrencilerin hazırbulunuşluk düzeyleri ile ilgili bir sorun yaşamadıklarını ifade etmiştir.

\subsection{5. Öğretmenlerden kaynaklı sorunlara yönelik bulgular}

Öğretmenlerden kaynaklanan sorunlar Tablo 6'da verilmiştir. Tablo 6 incelendiğinde öğretmenlerden kaynaklı sorunların deneyim ve eğitim yetersizliğinden kaynaklandığı görülmektedir.

Tablo 6: Öğretmenlerden kaynaklı sorunlar

\begin{tabular}{|c|c|c|}
\hline Kodlar & $\mathrm{f}$ & İfadeler \\
\hline Deneyim & 2 & $\begin{array}{l}\text {-Fen eğitimini yıllar geçtikçe öğrendim. Çünkü fen } \\
\text { eğitimimi çok iyi almadım (Ö12). } \\
\text {-Kendilerini yetiştirirlerse başarılı olurlar (Ö13). }\end{array}$ \\
\hline Eğitim yetersizliği & 2 & $\begin{array}{l}\text {-Yeni nesil kendini iyi yetiştirmiyor (Ö6). } \\
\text {-Sınıf ögretmenleri fen konularında yetersizler. Çünkü ona } \\
\text { yönelik çok fazla eğitim almadık. Bu da konuların tam } \\
\text { olarak anlatılmasını olumsuz yönde etkiliyor (Ö19). }\end{array}$ \\
\hline \multicolumn{3}{|c|}{$\begin{array}{l}\text { Öğretmenlerden kaynaklı sorunlara ait bulgulara göre deneyimsizlik ve } \\
\text { yetersizliği sorun oluşturmaktadır. Ancak bunların yanı sıra iki öğretmer } \\
\text { ğretmenlerinin fen ögretiminde yetersiz olduklarını düşünürken (Ö6; Ö19) } \\
\text { retmen sınıf öğretmenlerini fen öğretiminde yeterli görmektedir (Ö9; Ö1 } \\
\text { 3; Ö7; Ö8; Ö10; Ö11; Ö14; Ö15; Ö16; Ö17; Ö18; Ö20). Dört öğretmer } \\
\text { el yeterliliklerin eksik olduğunu düşünürken, üç öğretmen hiç ceva } \\
\text { miştir (Ö22; Ö20; Ö16). Sekiz öğretmen ise öğretmenlerin bireyse } \\
\text { liklerinde bir sorun olmadığını belirtmiştir (Ö1; Ö2; Ö6; Ö7; Ö8; Ö11; Ö12 } \\
\text { Ek olarak bir öğretmen görüșünü farklı șekilde belirtmiștir: " Fen alanındar }\end{array}$} \\
\hline
\end{tabular}


mezun olduğum için fen konularında sıkıntı yaşamıyorum ancak daha fazla deney ögrenmem iyi olabilir" (Ö20).

\subsection{Sınıf Öğretmenlerinin Fen Öğretimi Sürecinde Karşılaştığı Sorunların Çözüm Önerilerine Yönelik Bulgular}

Fen öğretim sürecinde karşılaşılan sorunlar için çözüm önerileri Şekil 2'de verilmiştir. Şekil 2'de parantez içlerinde belirtilen sayılar ifadelerin öğretmenler tarafından belirtilme sıklı̆̆ıdır.

Şekil 2. Fen öğretim sürecinde karşılaştıkları sorunların çözümüne yönelik bulgular

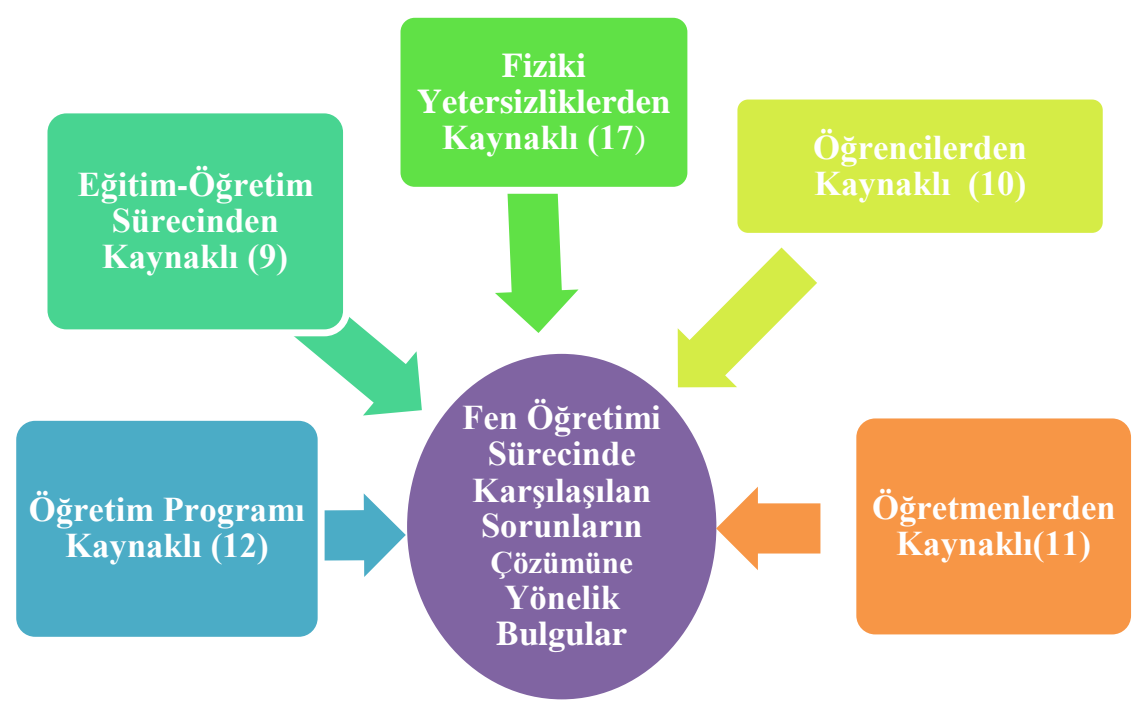

Sınıf öğretmenlerinin fen öğretim sürecinde karşılaş̧ıkları sorunlara yönelik sundukları çözüm önerileri beş alt tema altında toplanmıştır. Bu temalar; öğretim programı, eğitim-öğretim süreci, fiziki koşullar, öğrenci ve öğretmendir. Fen bilgisi öğretmenlerinin görüşleri doğrultusunda belirlenen temalara ilişkin ifadeler belirtilmiştir.

Öğretim programına ilişkin 12 öğretmen çözüm önerisinde bulunmuştur. $\mathrm{Bu}$ ögretmenlerin ifadeleri şu şekildedir;

• Dördüncü sınıflar için ders süresi uzatılmalıdır (Ö1; Ö3).

- Seviyeye göre konu dağılımı yapılmalıdır (Ö4; Ö5).

- Fen dersi için ayrılan süre uzatılmalıdır, dersler en az haftada beş saat olmalıdır (Ö8; Ö12). 
- Ders kitapları boş şeylerle doldurulmuş bunun yerine deney ve etkinliklere bol bol yer verilmelidir ( Ö6; Ö9).

- Program birleştirilmelidir. Dersler daha basit işlenmelidir. Eba video eğitim araçları daha çok hazırlanmalıdır (Ö10).

- Üçüncü sınıflar için üçüncü sınıf ders kitabını üçüncü sınıf öğretmeni hazırlamalıdır (Ö13).

- Üniteler yıllara bölünerek teferruatlı işlenmelidir. Her sene aynı konuya dönülmemelidir (Ö16).

- Öğretim programı daha ayrıntılı etkinlikler içermelidir. Öğretmenlere örnek etkinlikler sunulmalıdır (Ö19).

Eğitim-öğretim sürecinde karşılaşılan sorunlar alt temasına ilişkin dokuz öğretmen çözüm önerisinde bulunmuştur. Bu görüşler şu şekilde ifade edilmiştir;

- Yönetimsel sıkıntılar yaşıyoruz. Bu yüzden sınıfta kalma olmalı ve öğretmenin yaptırım gücü olmalıdır (Ö16).

- Sabahçı-öğlenci gruplar kaldırılarak öğretim tam gün yapılsın (Ö19).

- Sınıf mevcutları azaltılırsa her bir öğrenci ile ayrı ayrı ilgilenilebilir (Ö20).

- Süreçte yeterli malzeme ve materyaller temin edilmelidir (Ö4).

- Sınav sisteminin okulda işlenilen ders düzeyinde hazırlanması gerekir. Bu yüzden eğitim sistemi yeniden yapılandırılmalıdır. Eğer bir yapılandırılma gerekiyorsa bu önce pilot okullarda uygulanıp daha sonra diğer okullarda uygulanmalıdır (Ö8).

- Derslerde sınıflar arası geçişler zor olmamalıdır, dersler teorik değil uygulamaya yönelik olmalıdır, çocuğun anlayacağı düzeyde olmalıdır, gezi etkinliklerine daha çok yer verilmelidir (Ö3; Ö2; Ö1; Ö17).

Fiziki yetersizliklerden dolayı karşılaşılan sorunlar alt temasına ilişkin 17 öğretmen çözüm önerisinde bulunmuştur. Bu öneriler şu şekilde ifade edilmiştir;

- Laboratuvar kurulmalıdır ( Ö2; Ö7; Ö9; Ö12; Ö15; Ö16; Ö20).

- Okullara fen araç-gereçleri, deney malzemeleri ve materyaller sağlanmalıdır (Ö1; Ö3; Ö4; Ö5; Ö6; Ö8; Ö17; Ö19; Ö20).

- Akıllı tahta olmalıdır. Eğer akıllı tahta olursa görselleri hazırlayıp daha kolay konular anlatılabilir (Ö10).

Öğrenciden kaynaklı sorunlar alt temasına ilişkin 10 öğretmen çözüm önerisinde bulunmuştur. Bu öneriler şu şekilde belirtilmiştir;

- "Kalbur altı" çocuklarda bir şeyler olsa bile aile imkânı düşük olduğu için ister istemez çocuk bir yere gelemiyor, aile eğitimli olmalıdır, aileler 
bilinçlendirilmelidir, çocukların uyaranları ve aile ilgileri olmalıdır (Ö11; Ö12; Ö20; Ö5).

- Öğrenciler ders içi verimi arttırmak için evde kendileri okula hazırlık çalışmaları yapabilirler, evde deney ve gözlem yapabilirler, öğrenciler Türkçe gibi sözel derslerde okuduğunu anlama becerilerini geliştirmelidirler. Böylece fen konularını daha kolay anlayabilirler (Ö8; Ö6; Ö19).

- Ders gezilerle, bilim dergileriyle ve Televizyon programlarıla desteklenmelidir (Ö1; Ö3).

- Meraklı oldukları için sorun yok (Ö2).

Öğretmenlerden kaynaklı sorunlar alt temasına ilişkin 11 öğretmen çözüm önerisinde bulunmuştur. Bu öneriler şunlardır;

- Öğretmen derse hazırlıklı gelmelidir. Farklı yöntemler bulmalıdır. Deney ve gözleme yer vermelidir, yaş grubu küçük olduğu için dikkat süreleri az bu yüzden dikkat çekici etkinlikler yapmalıdır (Ö6; Ö16).

- Fen alanına yönelik hizmet içi eğitim kursları ve seminerlerine katılmalıdırlar. Ancak bu kurs ve seminerler uygulamalı yapılmalıdır (Ö1; Ö4; Ö19; Ö20).

- Sınıf öğretmenlerinin alan konusunda yetersiz olduklarını düşünüyorum. Bu yüzden eğitim fakültesinden mezun olurken yeterli düzeyde fen eğitimi ve laboratuvar eğitimi almaları önemlidir (Ö8).

- Alan yeterliliği olan öğretmenler 3. ve 4. Sinıf fen derslerine girmelidir (Ö12; Ö13).

- Fen eğitiminde yeterliyim. Çünkü program basit üniversite mezunu olan herkes fen bilgisini anlatabilir (Ö16).

- Öğrencilere daha çok araştırma ödevi vermelidirler (Ö17).

- Öğretmenler sadece derslerle uğraşmalıdırlar. Ancak bizler materyal hazırlama gibi pek çok işle uğraşıyoruz. Bu yüzden okulda fen sınıfları olmalıdır ve araçgereçler orada hazır olmalıdır (Ö10).

\section{TARTIŞMA ve SONUÇ}

Sınıf öğretmenlerinin fen öğretimi sürecinde karşılaş̧ıkları sorunlar ve bu sorunların çözümüne ilişkin görüşlerinin belirlenmesini amaçlayan bu çalışmada, sınıf öğretmenlerinin görüşleri doğrultusunda en sık rastlanan sorunların öğretim programından, eğitim-öğretim sürecinden, fiziki yetersizliklerden, öğrenciden ve öğretmenden kaynaklandığı belirlenmiştir. Sınıf öğretmenlerinin görüşlerine göre öğretim programı ile ilgili sorunların genellikle programın sürekli değişime uğramasından, öğrenci seviyesi üzerinde olmasından, çok yüzeysel olmasından, ders saatleri ve kitapların yetersiz olmasından kaynaklandığı belirtilmiştir. Bu ifadelerin aksine birkaç sınıf öğretmeni öğretim programındaki konuların ilgi çekici ve öğrenci seviyesine uygun olmasından dolayı sorun yaşamadıklarını ifade etmişlerdir. Bu sonuçlara paralel olarak fen bilgisi öğretmenlerinin fen öğretimi 
sürecinde karşılaştıkları sorunları belirlemek amacıyla öğretmen görüşlerinin alındığı bir başka çalışmada öğretim programının sürekli değişime uğraması, içeriğinin çok yoğun olması, öğrenci seviyesinde olmaması, sarmallık ilkesine göre düzenlenmemiş olması, ezbere dayalı olması, programın açıklayıcı olmamas1, beceri ve tutum kazandırmada yetersiz olması gibi etkenlerden dolay1 öğretim sürecinde sorun oluşturduğu belirtilmiştir Balbağ\&Karaer, 2016). Öğretim programı kaynaklı sorunların tespit edildiği diğer çalışmalara göre, Fen ve teknoloji öğretim programında etkinliklerin uygulanması için zamanın yeterli olmadığı (Akınc1, Uzun,\&Kışoğlu, 2015; Doğan 2010; Ayvac1 ve Durmuş 2013; Arı 2010) ve yapılandırmacı yaklaşımın gerekliliklerinden dolayı öğrencilerin üst düzey becerilerinin sınavlarla ölçülmesinin zor olduğu belirtilmiştir. Bu yüzden üst düzey davranışları ölçen sorularla değerlendirmenin gerekliliği vurgulanmıştır (Ayvacı ve Türkdoğan 2010). Dershane ve okullarda yapılan deneme sınavlarının yapılandırmacı program ile çelişmesi yine öğretim program kaynaklı bir sorun olarak belirtilmiştir (Küçüköner, 2011). Sınıf öğretmenlerinin görüşleri doğrultusunda ayrıntılı ders işlenmesi, kaynak eksikliği ve etkinliklerin yapılamaması eğitim-öğretim sürecinde karşılaşılan sorunlar olarak belirtilmiştir. Benzer bir çalışmada, öğrenci çalışma kitaplarında yer alan etkinliklerin yetersiz kalması Küçüköner (2011) tarafından sorun olarak dile getirilmiştir. Yapılan bu çalışmada sınıf öğretmenlerinin görüşleri doğrultusunda, fiziki yetersizlikler ile ilgili yaşanılan sorunlarda çoğunlukla laboratuvar eksiklikleri ve sınıf mevcudu sorun olarak dile getirilmiştir. Sınıf öğretmenlerinin fen öğretim sürecinde karşılaştıkları sorunlara benzer olarak, sınıfların kalabalık oluşu (Doğan 2010; Yeşilyurt 2012; Aydın ve Çakıroğlu 2010; Bayraktar ve Çınar 2010; Kurtuluş ve Çavdar 2011; Geçer ve Özel 2012; 2013; Çiftçi 2010; Akıncı ve ark. 2015; Türkmen ve Kandemir 2011) laboratuvarların yetersizliği (Doğan 2010), sınıfların fiziki durumunun yetersizliği (Doğan 2010), materyal eksikliği (Geçer ve Özel 2012; Aydın ve Çakıroğlu 2010), okulların yeterli altyapıya sahip olmaması (Küçüköner 2011), teknolojik yetersizlikler (Akıncı ve ark. 2015) sorun olarak dile getirilmiştir. Sınıf öğretmenleri fen öğretimi sürecinde öğrencilerden kaynaklı sorunlar olarak çoğunlukla bireysel farklılıklar ve çevresel durumların yer aldığını belirtmişlerdir. Öğrencilerin tutum ve hazırbulunuşluk düzeylerinin yeterli olmadığı (Akıncı ve ark. 2015; Türkmen ve Kandemir; 2011), öğrencilerin ilkokullardan önbilgi açısından eksik gelmesi (Küçüköner 2011), öğrencilerin motivasyon eksikliği (Cengiz, Uzoğlu\&Daşdemir, 2012) fen öğretim sürecinde öğrencilerden kaynaklı sorunlar olarak dile getirilmiştir. Sınıf öğretmenlerinin görüşleri doğrultusunda fen öğretim sürecinde öğretmenlerden kaynaklı sorunlar olarak deneyim ve eğitim yetersizliğini belirttikleri ancak genel olarak kendilerini fen öğretimi sürecinde yeterli gördüklerini ifade etmişlerdir. İlgili çalışmalarda sınıf öğretmenlerinin çoğunlukla fen bilimleri öğretiminde öz-yeterlik konusunda, bilimsel süreç becerilerinin analizinde yetersizlik, fen alanına hâkim olamama gibi konularda sorunlar yaşadıkları belirtilmiştir (Akbaş\&Çelikkaleli, 2006; Gömleksiz, Kan\&Biçer, 2010; Türkmen\&Kandemir, 2011; Türkmen, 2002). Küçük, Altun\&Paliç (2003) ise sınıf öğretmenleri üzerine yaptıkları çalışmada öğretmenler arası işbirliğinin önemini vurgulamışlar ve sınıf öğretmenlerinin fen bilimleri öğretmenleri ile daha aktif bir iletişim ve işbirliği içinde bulunmaları 
halinde onların fen öğretiminde öz-yeterlik inançlarının artabileceği belirtmişlerdir. Bu sonuçlar doğrultusunda aşağıdaki öneriler verilebilir;

- Sinıf öğretmenlerinin fen öğretimi sürecinde karşılaştıkları sorunları en aza indirebilmek için sınıf öğretmenlerinin süreçte yaşadıkları sorunları ortaya çıkarmak için daha fazla öğretmen görüşünün alındığı çalışma yapılabilir.

- Ders saatlerinin yetersiz olmasından dolayı program ayrıntılarıyla okutulamadığı ve etkinliklerin yapılamadığı belirtilmektedir. Bu yüzden fen bilimleri derslerinin süreleri arttırılabilir.

- Sınıf öğretmenleri okullarda laboratuvar, deney malzemeleri ve teknolojik araç-gereçlerin eksikliğinden dolayı fen öğretim programında yer alan etkinlikleri yapamadıklarını ifade etmektedirler. Bu yüzden okullara yeterli sayıda araç gereç ve laboratuvar temini yapılmalıdır. Ek olarak fen öğretim programında yer alan bütün etkinlikler üst düzey araç ve gereçleri gerektirmemektedir. Bu yüzden sınıf öğretmenlerine de bu konuda büyük işler düşmektedir. Onlarda öğrenci ve okul imkânlarına uygun etkinlikler seçerek öğretimde yaşanan sorunları azaltabilirler.

- Çalışma sonunda sınıf öğretmenlerinin genelinin hizmet içi eğitim seminerlerine katıldıkları görülmüştür. Buna ek olarak lisansüstü eğitimlere başvurarak eksik oldukları konuları tamamlayabilirler ya da teknolojik yenilikleri daha yakından takip edebilirler.

- Öğrenci hazırbulunuşluğunu arttırmak için öğrencilerin bireysel farklılıklarını daha çok dikkate alarak ders etkinlikleri geliştirilebilir. 


\section{KAYNAKLAR}

Akbaş, A., \& Çelikkaleli, Ö. (2006). Sınıf öğretmeni adaylarının fen öğretimi özyeterlik inançlarının cinsiyet, öğrenim türü ve üniversitelerine göre incelenmesi. Mersin Üniversitesi Eğitim Fakültesi Dergisi, 2(1), 98-110.

Akıncı, B., Uzun, N., \& Kışoğlu, M. (2015). Fen bilimleri öğretmenlerinin meslekte karşılaştıkları problemler ve fen öğretiminde yaşadıkları zorluklar. International Journal of Human Sciences, 12(1), 1189-1215.

Aydın, S., \& Çakıroğlu, J. (2010). İlköğretim fen ve teknoloji dersi öğretim programına ilişkin öğretmen görüssleri: Ankara örneği. İlköğretim Online, 9(1), 301-315.

Ayvacı, H. Ş., \& Bakırcı, H. (2012). Fen ve teknoloji öğretmenlerinin fen öğretim süreçleriyle ilgili görüşlerinin 5E modeli açısından incelenmesi. Türk Fen Eğitimi Dergisi, 9(2), 132-151.

Ayvac1, H. Ş., \& Durmuş, A. (2013). Fen ve teknoloji öğretmenlerinin mesleklerinin ilk yıllarında karşılaştıkları sorunlar ve bu sorunların yıllara göre değişimi. Kazım Karabekir Eğitim Fakültesi Dergisi, 27(1).

Ayvacı, H. Ş., \& Türkdoğan, A. (2010). Yeniden yapılandırılan Bloom taksonomisine göre fen ve teknoloji dersi yazılı sorularının incelenmesi. Türk Fen Ĕ̆itimi Dergisi, 7(1), 13-25.

Balbağ, M. Z., \& Karaer, G. (2016). Fen bilgisi öğretmenlerinin fen öğretiminde karşılaştıkları sorunlara yönelik öğretmen görüşleri. Eğitim ve Öğretim Araştırmaları Dergisi, 5(3), 1-11.

Balbağ, M. Z., Leblebiciler, K., Karaer, G., Sarıkahya, E., \& Erkan, Ö. (2016). Türkiye'de fen eğitimi ve öğretimi sorunları. Eğitim ve Öğretim Araştırmaları Dergisi, 5(3), 12-23.

Bayraktar, Ş., \& Çınar, D. (2010). Öğretmen adaylarının gözü ile fen ve teknoloji öğretmenlerinin etkili öğretmen davranışlarını gerçekleştirme düzeyleri. Ahi Evran Üniversitesi Eğitim Fakültesi Dergisi, 11(3), 131-15.

Büyüköztürk, Ş., Kılıç, E., Akgün, Ö., Karadeniz, Ş., \& Demirel, F. (2009). Bilimsel araştırma yöntemleri. (4. Basım). Ankara: Pegem A Yayıncılık.

Cengiz, E., Uzoğlu, M., \& Daşdemir, İ. (2012). Öğretmenlere göre fen ve teknoloji dersindeki başarısızlık nedenleri ve çözüm önerileri. Erzincan Üniversitesi Ĕ̈itim Fakültesi Dergisi, 14(2), 393-418.

Çiftçi, S. (2010). İlköğretim birinci kademe 4. ve 5. sınıf öğretmenlerinin performans görevlerine ilişkin görüşleri. Illköğretim Online, 9(3), 934-951.

Doğan, Y. (2010). Fen ve teknoloji dersi programının uygulanması sürecinde karşılaşılan sorunlar. Yüzüncü Yıl Üniversitesi Eğitim Fakültesi Dergisi, 7(1), 86-106.

Geçer, A., \& Özel, R. (2012). İlköğretim fen ve teknoloji dersi öğretmenlerinin öğrenme-öğretme sürecinde yaşadıkları sorunlar. Kuram ve Uygulamada Ĕ̈itim Bilimleri, 12(3), 2237-2261. 
Gömleksiz, M. N., Kan, A. Ü., \& Biçer, S. (2010). Sınıf öğretmenlerinin fen ve teknoloji dersini yürütmeye yönelik özyeterlikleri. Cumhuriyet Üniversitesi Sosyal Bilimler Dergisi, 34(2), 21-30.

Hasan, G., Deniş, H., \& Demirkaya, H. (2010). Sınıf öğretmeni adaylarının fen bilgisi öğretimi dersine yöneliktutumlarının çeşitli değişkenlere göre incelenmesi. Mehmet Akif Ersoy Üniversitesi Fen Bilimleri Enstitüsü Dergisi, 1(2), 133-149.

Kurtuluş, N., \& Çavdar, O. (2011). Fen ve teknoloji öğretim programındaki etkinliklere yönelik öğretmen ve öğrenci düşünceleri. Necatibey Eğitim Fakültesi Elektronik Fen ve Matematik Ë̆itimi Dergisi, 5(1), 1-23.

Küçük, M., Altun, E., \& Paliç, G. (2013). Sinıf öğretmenlerinin fen öğretimi özyeterlik inançlarının incelenmesi: Rize ili örneklemi. Amasya Üniversitesi Eğitim Fakültesi Dergisi, 2(1), 45-70.

Küçüköner, Y. (2011). 2005 Fen ve teknoloji dersi öğretim programının uygulanmasında karşılaşılan sorunlar ve öğretmen gözüyle çözüm önerileri. Erzincan Eğitim Fakültesi Dergisi, 13(2), 11-37.

MEB. (2006). İlköğretim Fen ve Teknoloji Dersi (6, 7 ve 8. Sinıflar) Öğretim Programı. Ankara: Milli Eğitim Bakanlığı.

MEB. (2013). İlkögretim Kurumları (İlkokullar ve Ortaokullar) Fen Bilimleri Dersi (3, 4, 5, 6, 7 ve 8. sinfflar) Öğretim Programı. Ankara: Milli Eğitim Bakanlığ 1 .

MEB. (2017). Fen Bilimleri Dersi Öğretim Programı (Illkokul ve Ortaokul 3, 4, 5, 6, 7 ve 8. Sinıflar). Ankara: Milli Eğitim Bakanlığı.

Trowbridge, L., Bybee, R., \& Powell, J. (2004). Teaching secondary science: strategies for developing scientific literacy.

Türkmen, L. (2002). Sınıf öğretmenliği 1. sınıf öğrencilerinin fen bilimleri ve fen bilgisi öğretimine yönelik tutumları. Hacettepe Üniversitesi Ĕgitim Fakültesi Dergisi, 23(23), 218-228.

Türkmen, H., \& Kandemir, E.M. ( 2011). Öğretmenlerin bilimsel süreç becerileri öğrenme alanı algıları üzerine bir durum çalışması. Journal of European Education, 1(1), 15-24.

Yeşilyurt, E. (2012). Fen ve teknoloji dersinde kullanılan ölçme-değerlendirme yöntemleri ve karşılaşllan güçlükler. Turkish studies-International Periodical for Languages, Literature and History of Turkish or Turkic, 7(2), 1183-1205. 


\section{EXTENDED ABSTRACT}

\section{Introduction}

Today, with increasing production of scientific knowledge, the influence of science is clearly observed in every area of our lives. Accordingly, science education plays an important and key role for the future of societies. At elementary school level, science instruction is delivered by elementary school teachers. With the science instruction curriculum revised in 2013, the science course started to be taught as of the third grade. Considering that students' first encounter with science is in this period, elementary school teachers have a special liability in teaching the science course (Genç, Deniş \& Demirkaya, 2010). In order for elementary school teachers to fulfil this responsibility, the problems experienced in science instruction should be minimized. Studies in the literature show that many problems are encountered in science instruction. However, most of these studies focused on the problems that science teachers had in their science classes. It is notable that there is limited research on elementary school teachers' science instruction by taking teacher views and addressing the problems in a holistic perspective. Researchers investigated problems in the science instruction process such as measurement and assessment, the practice stage of the 5E model, science lab activities, science and technology course curriculum, lack of equipment, student misbehavior, teachers' low self-efficacy beliefs, and their incompetence in science (Balbağ \& Karaer, 2016, Ayvacı \& Durmuş, 2013; Ayvacı \& Bakırc1, 2012; Kaya \& Böyük, 2011; Doğan, 2010; Küçüköner, 2011). In this respect, this study has significance in terms of addressing the problems encountered in science instruction based on the views of elementary school teachers who have an important role in this process.

The aim of the study was to reveal the problems that elementary school teachers have in science instruction, and their suggestions regarding these problems. In line with this aim, the following research questions were addressed:

What are the problems that elementary school teachers encounter in science instruction?

What are elementary school teachers' suggestions regarding the problems they encounter in science instruction?

\section{Method}

The qualitative research method was adopted in the study. In this respect, semi-structured interview technique, a qualitative research method, was used to gather the data. The semi-structured interview form consisted of two sections. The first section included questions related to the elementary school teachers' gender, year of service, area of undergraduate study, and state of having received training on science instruction other than in undergraduate education. The second section, on the other hand, contained questions towards revealing elementary school teachers' problems in science instructions, and their suggestions regarding these 
problems. An interview from 30 to 45 minutes was conducted with every teacher to gather the data. During the interviews, the data were gathered through the interview forms and audio recording. The data were analyzed by using the inductive analysis method. In order to enhance the reliability of the study, the data were analyzed by two independent researchers. In the following process, the codes and themes were compared, the areas of disagreement were determined, and then the themes were finalized after further negotiations. The participants of the study were 20 elementary school teachers teaching third and fourth graders in the Eskisehir province during the spring semester of the 2015-2016 school year. 13 female and 7 male teachers participated in the research.

\section{Results and Discussion}

The findings obtained from the study are presented under the themes "Elementary School Teachers' Views on the Problems They Encounter in Science Instruction" and "Elementary School Teachers' Views on the Solution of the Problems They Encounter in Science Instruction".

The elementary school teachers' views on the problems they encounter in science instruction showed that these problems stemmed from the curriculum, instructional process, physical deficiencies, students and the teacher. While most of the elementary school teachers stated that the problems they had were due to the science curriculum, some teachers said they did not have any problems related to the curricula. They teachers who reported to have problems in the instructional process stated that they used different resourced due to the insufficiency of course hours and course books. As for the problems related to physical deficiencies, the teachers said they had problems mostly in inadequacy of lab facilities and experimental equipment. Moreover, class size was also mentioned as a problem, whereas several teachers did not state physical deficiencies to be a problem. Regarding student-related problems, the elementary school teachers said students' individual differences and readiness levels posed a problem. As for teacher-related problems, the issues seen as a problem included teachers' inexperience and lack of adequate training. However, most of the teachers perceived themselves as competent in science instruction.

Elementary school teachers' suggestions regarding the problems they encounter in science instruction were addressed under five themes. These themes included curriculum, instructional process, physical conditions, students and the teacher. The statements are presented with respect to the themes bases on the elementary school teachers' views. The teachers suggested that the curriculum should be more detailed, and provide them with sample activities. For the problems encountered in the instructional process, they stated that class sizes should be reduced, double shift schooling omitted and full day education given in schools, and the test system be at the level of classes delivered at school. Regarding the problems due to physical deficiencies, they said that the school should have a laboratory, smart boards and experimental equipment. As a solution for student-related problems, the elementary school teachers said students' 
individual differences and readiness levels posed a problem. For the teacherrelated problems, they said teachers should come to class in time, use attentiongetting activities and enhance their competence in science instruction. Based on the elementary school teachers' views, the most common problems encountered in science instruction were found to be related to the curriculum, instructional process, physical deficiencies, students and the teacher. Similar problems were also reported by other studies in the literature. Teachers were reported to state that they have problems in the instructional process due to frequent changes, density of the content, inconsistency with students' level, and being inadequate for developing skills and attitudes (Balbağ\&Karaer, 2016), there is not enough time for implementing the activities in the science and technology course curriculum (Akınc1, Uzun,\&Kışoğlu, 2015; Doğan 2010; Ayvacı \& Durmuş 2013; Arı 2010), students' attitudes and readiness levels are not sufficient (Akınc1 et al. 2015; Türkmen \& Kandemir, 2011), and most elementary school teachers are not competent in science and analysis of scientific processes (Akbaş \& Çelikkaleli, 2006; Gömleksiz, Kan \& Biçer, 2010; Türkmen \& Kandemir, 2011; Türkmen, 2002). Based on these results, the following suggestions can be offered:

- Further studies that would reveal the problems experienced in science instruction should be conducted to minimize such problems that elementary school teachers have.

- The duration of science classes can be lengthened.

- Sufficient amount of tools and equipment should be provided to schools.

- In the study, most of the elementary school teachers stated to have attended in-service trainings. Additionally, they can improve their knowledge and skills or follow technological novelties more closely by pursuing postgraduate studies.

- In order to enhance students' readiness levels, instructional activities should be developed by taking into account individual differences. 